\title{
Pseudobutyrivibrio ruminis gen. nov., sp. nov., a Butyrate-Producing Bacterium from the Rumen That Closely Resembles Butyrivibrio fibrisolvens in Phenotype
}

\author{
N. O. VAN GYLSWYK, ${ }^{1 *}$ H. HIPPE, ${ }^{2}$ AND F. A. RAINEY ${ }^{2}$ \\ Department of Animal Nutrition and Management, Swedish University of Agricultural Sciences, Kungsängen \\ Research Centre, S-75323 Uppsala, Sweden, ${ }^{1}$ and Deutsche Sammlung von Mikroorganismen \\ und Zellkulturen GmbH, D-38124 Braunschweig, Germany ${ }^{2}$
}

\begin{abstract}
A gram-negative, anaerobic, non-spore-forming bacterium which is a curved rod and motile by means of a single polar or subpolar flagellum was isolated from the rumen of a cow on pasture. The bacterium fermented a range of carbohydrates. Glucose was fermented to formate, butyrate, and lactate. The composition of cellular fatty acids was determined. The DNA base composition was 40 to $41 \mathrm{~mol} \% \mathrm{G}+\mathrm{C}$. The complete 16S rRNA sequence (EMBL accession number, X95893) was obtained, and the phylogenetic relationships were determined. The most closely related taxa were Roseburia cecicola, Eubacterium rectale, and Lachnospira pectinoschiza. The name proposed for this bacterium is Pseudobutyrivibrio ruminis gen. nov., sp. nov.; the type strain is A12-1 (DSM 9787).
\end{abstract}

During a search for ruminal bacteria capable of metabolizing succinate, using an enrichment procedure, a culture was obtained from which a non-succinate-fermenting bacterium was isolated that closely resembled Butyrivibrio fibrisolvens in a number of phenotypical characteristics. In this paper we show that this bacterium differs sufficiently from the genus Butyrivibrio to justify placing it in a new genus. The name proposed is Pseudobutyrivibrio ruminis gen. nov., sp. nov.

\section{MATERIALS AND METHODS}

Isolation. Isolation procedures and composition of basal media were as described previously (29).

A $1-\mathrm{ml}$ portion of the $10^{-8}$ dilution of homogenized, whole-rumen contents from a cow on pasture (no concentrate was fed) was added to $6 \mathrm{ml}$ of enrichment medium containing clarified rumen fluid $(40 \%)$ and disodium succinate (40 $\mathrm{mM}$ ). The medium was incubated until turbidity appeared ( 3 days), after which time bacteria were isolated by using a roll bottle technique. From one of the colonies picked (designated A12), bacteria that fermented succinate were obtained. However, reisolation showed that it was not pure, and an isolate which was subsequently found not to be able to ferment succinate, although cell morphology resembled that of the mixed culture, was obtained. This strain (strain A12-1 ) was characterized and is the subject of the present study.

Characterization tests. Media and methods used for the various tests were described previously (29). Modifications or additions are given below.

Microscopic evidence of motility was confirmed by Leifson staining of the flagella (7). Ability to ferment the Na salts of acidic substrates was assessed by measuring the change in optical density $(600 \mathrm{~nm})$, while ability to ferment nonacidic substrates was assessed by measuring the changes in $\mathrm{pH}$ of poorly buffered media prepared with $20 \%$ of the concentration of $\mathrm{NaHCO}_{3}$ in basal medium, adjusting the $\mathrm{pH}$ to about 6.8. $\mathrm{O}_{2}$-free $\mathrm{N}_{2}$ replaced $\mathrm{CO}_{2}$. Substrates were added to sterile media as concentrated, filter-sterilized solutions, except for xylan and soluble starch, which were heat sterilized. Glucose $(1 \%)$ was included as an energy source in media for testing tolerance to $\mathrm{O}_{2}$ and different temperatures; ability to liquefy gelatin; production of catalase, urease, and $\mathrm{H}_{2} \mathrm{~S}$; reduction of nitrate; and for the production of cells used for determining $\mathrm{G}+\mathrm{C}$ mol\%. The medium for $\mathrm{H}_{2} \mathrm{~S}$ production contained $30 \mathrm{~g}$ of SIM medium (DIFCO) per liter.

Lipid analysis. Strain A12-1 ${ }^{\mathrm{T}}$ was grown in basal medium (29) containing $0.4 \%$ glucose and in a similar medium from which rumen fluid was either omitted or replaced with a volatile fatty acid mixture as formulated by Caldwell and Bryant (3). Inocula constituted $0.5 \%$ of the total volume. After growth for $15 \mathrm{~h}$, when

* Corresponding author. Mailing address: Department of Animal Nutrition and Management, Swedish University of Agricultural Sciences, Kungsängen Research Centre, S-75323 Uppsala, Sweden. Fax: (46) 18672946 . the cultures had reached the stationary phase, cells were sedimented by centrifugation, washed three times in $1 \% \mathrm{NaCl}$, and stored at $-20^{\circ} \mathrm{C}$. The fatty acid methyl esters were prepared from the wet cells by saponification, methylation, and extraction $(14,27)$. The fatty acid methyl ester mixtures were separated by gas-liquid chromatography with the Microbial Identification System (Microbial ID, Newark, Del.) (14). Peaks were automatically integrated, and fatty acid identities and percentages were calculated by using the Microbial Identification System Library Generation Software (Microbial ID).

G+C mol\%. Cells were lysed with sodium dodecyl sulfate (13). DNA was isolated and purified (15), and the $\mathrm{G}+\mathrm{C}$ content was estimated from the ratio $A_{245} / A_{270}(26)$. DNAs from Escherichia coli $\mathrm{B}$, Micrococcus luteus, and calf thymus (all purchased from Sigma) served as calibration standards.

Phylogenetic analysis. Genomic DNA extraction, PCR-mediated amplification of the DNA coding for $16 \mathrm{~S}$ rRNA (16S rDNA), and purification of PCR products were carried out as described previously $(21,22)$. Purified PCR products were sequenced with the Taq Dye-Deoxy Terminator Cycle Sequencing Kit (Applied Biosystems, Weiterstadt, Hessen, Germany) as directed in the manufacturer's protocol. Sequence reaction mixtures were electrophoresed with the Applied Biosystems 373A DNA Sequencer. The 16S rDNA sequences were aligned manually against representatives of the low-GC subphylum of the grampositive bacteria.

Pairwise evolutionary distances were computed with the correction of Jukes and Cantor (11). The neighbor-joining method of Saitou and Nei (23) was used in the construction of the phylogenetic dendrogram from distance matrices.

Nucleotide sequence accession number. The nucleotide sequence determined in this study has been deposited in the EMBL database under accession no. X95893.

\section{RESULTS AND DISCUSSION}

Strain $A 12-1^{\mathrm{T}}$ is a gram-negative, curved rod with a single polar or subpolar flagellum; it is a strict anaerobe and does not produce spores. It ferments a range of carbohydrates, producing formate, butyrate, and lactate from glucose. These properties, together with the fact that the $\mathrm{G}+\mathrm{C}$ mol\% of the DNA is 40 to 41 , would have sufficed for classifying strain $\mathrm{A} 12-1^{\mathrm{T}}$ as Butyrivibrio fibrisolvens according to earlier definitions of the species $(2,9,25)$.

Relatedness to other taxa. 16S rDNA sequence analysis shows strain A12-1 ${ }^{\mathrm{T}}$ to fall within cluster XIVa (4) of the clostridia and related organisms. Strain A12-1 ${ }^{\mathrm{T}}$ clusters within a group of phylogenetically related but yet physiologically and morphologically distinct taxa. The highest $16 \mathrm{~S}$ rDNA sequence similarity values found are those to Roseburia cecicola $(92.6 \%)$ and Eubacterium rectale (92.6) (Table 1). Within cluster XIVa, representatives of eight validly described genera are found to group together. The degree of sequence divergence between 


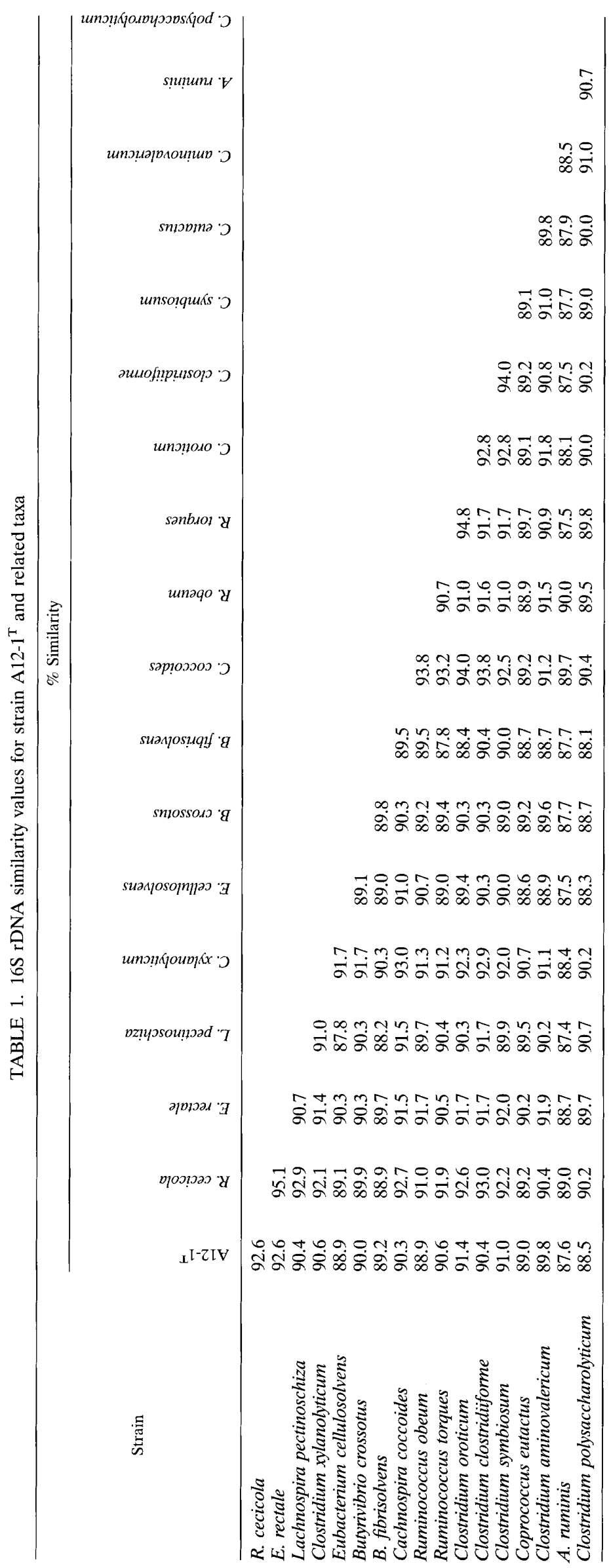




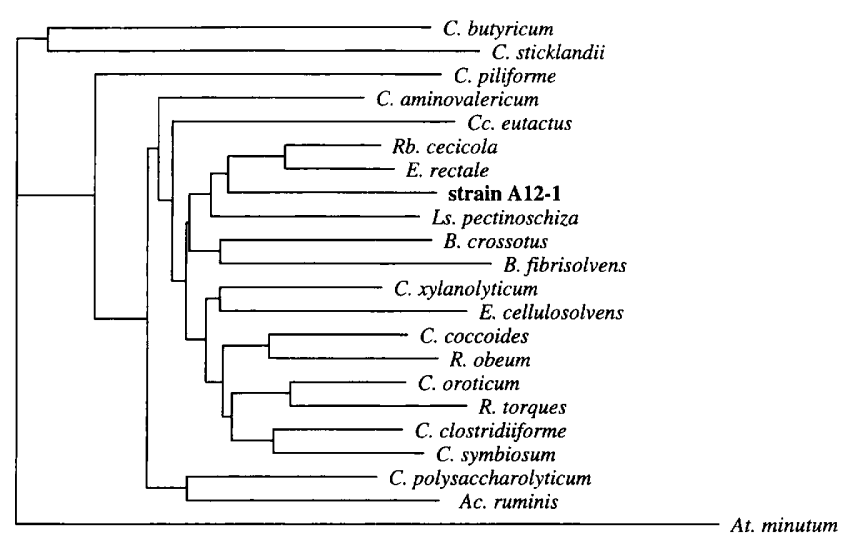

0.10

FIG. 1. Phylogenetic dendrogram indicating the position of strain A12-1 ${ }^{\mathrm{T}}$ within the radiation of representatives of cluster XIVa (4) of the clostridia and their relatives. The position of the root was determined by including the actinomycete Atopobium minutum as an outgroup organism. The scale bar represents 10 nucleotide substitutions per 100 nucleotides.

these taxa is around 8 to $12 \%$ (Fig. 1). Strain A12-1 ${ }^{\mathrm{T}}$ shows sequence divergence in this range to all taxa within the same phylogenetic cluster. Table 2 shows some of the phenotypical characteristics distinguishing strain $\mathrm{A} 12-1^{\mathrm{T}}$ from neighboring taxa. In combination with phenotypical and physiological data, the 16S rDNA sequence data support the designation of strain A12-1 ${ }^{\mathbf{T}}$ as a new genus.

Description of Pseudobutyrivibrio gen. nov. Pseudobutyrivibrio (Pseu.do. Gr. adj. pseudes, false; butyrivibrio, from the genus Butyrivibrio; L. masc. n. Pseudobutyrivibrio, not a true butyrivibrio). The genus comprises bacteria that are non-spore-forming, gram-negative anaerobic rods that ferment a variety of carbohydrates, with butyrate as an important end product. They are neither xylanolytic, amylolytic, nor proteolytic (do not liquefy gelatin). Cellular fatty acids do not include 18:1 unsaturated fatty acids. The $\mathrm{G}+\mathrm{C}$ content of the DNA is about 40 mol\%.

Description of Pseudobutyrivibrio ruminis sp. nov. Pseudobutyrivibrio ruminis (ru'mi.nis. L. neut. gen. n. ruminis, of the rumen). Cells are gram-negative, curved rods, often with tapering ends. Spores are not produced. Cells are motile by means of a single polar or subpolar flagellum. Cell width varies from 0.3 to $0.5 \mu \mathrm{m}$. The length of most cells varies between 1 and $3 \mu \mathrm{m}$ (Fig. 2A), while very long cells often occur, particularly when grown on agar medium (Fig. 2B). When bacteria are mixed with rumen fluid-yeast extract-glucose-agar medium and cultured in roll bottles for $24 \mathrm{~h}$, the colonies produced are convex, round with a smooth edge, and opaque with striations radiating from the center which cover about two-thirds of the inner area of colonies. Colony diameters vary from 1.5 to $2 \mathrm{~mm}$. Submerged colonies are lens-shaped discs with diameters of about $0.5 \mathrm{~mm}$.

Growth characteristics. Strain A12-1 ${ }^{\mathrm{T}}$ ferments the following carbohydrates (final $\mathrm{pH}$ in parentheses): arabinose (5.1), cellobiose (5.1), fructose (5.0), galactose (5.1), glucose (5.0), lactose (5.3), maltose (5.1), mannose (5.4), sucrose (5.1), trehalose (5.1), and xylose (5.1). Glycerol is weakly fermented (5.9), and the following do not support growth: mannitol, ribose, sorbitol, soluble starch, xylan, lactate, succinate, fumarate, oxalate, pyruvate, malonate, malate, aspartate, and glutamate. Glucose $(50 \mathrm{mM})$ is fermented to formate $(29 \mathrm{mM})$, butyrate $(19 \mathrm{mM})$, lactate $(40 \mathrm{mM})$, and a small amount of acetate (less than $1 \mathrm{mM}$ ). Types and amounts of gases produced were not determined. The maximum optical densities (600 $\mathrm{nm}$, in tubes of $13.5 \mathrm{~mm}$ [inside diameter]) reached in medium containing rumen fluid $(40 \%)$, yeast extract $(0.5 \%)$, and glucose $(50 \mathrm{mM})$ and in similar media from which either

TABLE 2. Some characteristics distinguishing $P$. ruminis from taxa showing genotypical relatedness ${ }^{a}$

\begin{tabular}{|c|c|c|c|c|c|c|c|}
\hline Characteristic & $\begin{array}{l}\text { Pseudobutyrivibrio } \\
\text { ruminis } \mathrm{A} 12-1^{\mathrm{T}}\end{array}$ & $\begin{array}{l}\text { Roseburia } \\
\text { cecicola }\end{array}$ & $\begin{array}{l}\text { Eubacterium } \\
\quad \text { rectale }\end{array}$ & $\begin{array}{l}\text { Lachnospira } \\
\text { pectinoschiza }\end{array}$ & $\begin{array}{l}\text { Coprococcus } \\
\text { eutactus }\end{array}$ & $\begin{array}{l}\text { Butyrivibrio } \\
\text { fibrisolvens }\end{array}$ & $\begin{array}{l}\text { Butyrivibrio } \\
\text { crossotus }\end{array}$ \\
\hline Cell shape & Curved rods & Curved rods & Curved rods & $\begin{array}{l}\text { Coccoid to } \\
\text { straight rods }\end{array}$ & Cocci & Curved rods & Curved rods \\
\hline Flagella & $\begin{array}{l}\text { Monotrichous, polar } \\
\text { to subpolar }\end{array}$ & $\begin{array}{l}\text { One subpolar } \\
\text { bundle per cell }\end{array}$ & $\begin{array}{l}\text { Polar to subpolar, } \\
\text { singly, in pairs } \\
\text { or tufts }\end{array}$ & Peritrichous & None & $\begin{array}{l}\text { Monotrichous, } \\
\text { polar to sub- } \\
\text { polar }\end{array}$ & $\begin{array}{l}\text { Lophotrichous } \\
\text { polar to sub- } \\
\text { polar }\end{array}$ \\
\hline Gram reaction & - & - & + & + & + & - & - \\
\hline \multicolumn{8}{|l|}{ Substrate utilized } \\
\hline Cellobiose & + & + & + & + & + & + & - \\
\hline Fructose & + & - & + & $+^{b}$ & + & + & w \\
\hline Sorbitol & - & + & $\mathrm{v}$ & - & - & - & - \\
\hline Starch & - & + & + & - & + & $\mathrm{v}$ & + \\
\hline Sucrose & + & + & + & - & + & $\mathrm{v}$ & - \\
\hline Xylose & + & + & + & - & - & v & - \\
\hline $\begin{array}{l}\text { Major fermentation } \\
\text { products }^{c}\end{array}$ & $\mathrm{~F}, \mathrm{~B}, \mathrm{~L}$ & $\mathrm{~B}, \mathrm{E}$ & $\mathrm{B}, \mathrm{L}$ & $\mathrm{F}, \mathrm{A}, \mathrm{E}$ & $\mathrm{F}, \mathrm{A}, \mathrm{B}, \mathrm{L}$ & $\mathrm{F}, \mathrm{B}(\mathrm{A}, \mathrm{L})$ & $\mathrm{F}, \mathrm{A}, \mathrm{B}, \mathrm{L}$ \\
\hline $\mathrm{G}+\mathrm{C}$ mol $\%$ of DNA & $40-41$ & $42-43$ & 38 & 42 & 41 & 41 & $36-37$ \\
\hline Reference(s) & & 24 & $7,17,18,20^{d}$ & 5 & 8 & $1,12,{ }^{d} 28^{d}$ & 19 \\
\hline
\end{tabular}

“All taxa listed are non-spore-forming, mesophilic, strictly anaerobic, intestinal bacteria. + , positive; -, negative; v, variable; w, weak.

${ }^{b}$ Positive only on prolonged incubation.

" F, formate; A, acetate; B, butyrate; L, lactate; E, ethanol. Parentheses denote that the product may or may not be produced.

${ }^{d}$ References important for values of $\mathrm{G}+\mathrm{C}$ mol\% of DNA. 

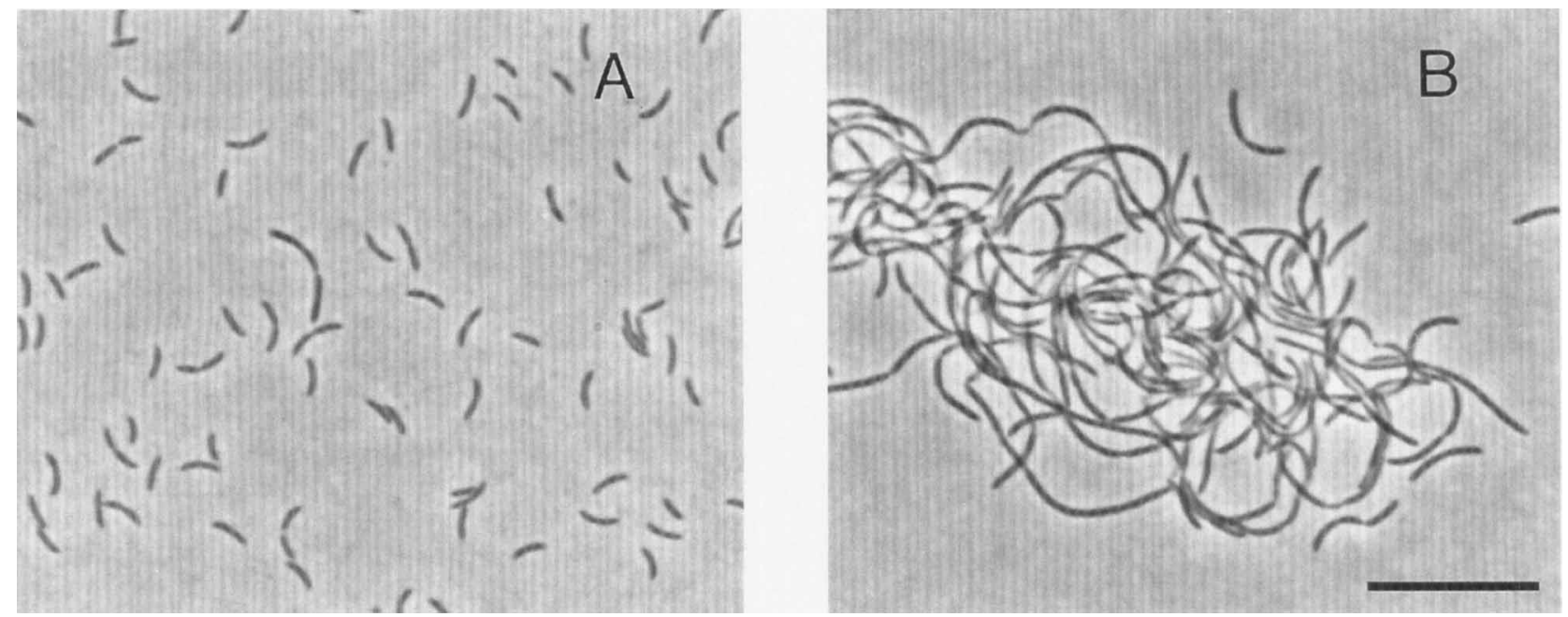

FIG. 2. Phase-contrast micrographs (taken with an Axiophot from Zeiss, Oberkochen, Germany) of cells of strain A12-1 ${ }^{\mathrm{T}}$ grown with $5 \mathrm{~g}$ of glucose per liter for $15 \mathrm{~h}$ in liquid medium (A) and on an agar slant (B). Bar $=10 \mu \mathrm{m}$.

rumen fluid, yeast extract, or glucose was omitted were 1.8, 1.2, 0.5 , and 0.2 , respectively. Hourly optical density measurements in medium containing $50 \mathrm{mM}$ glucose, $40 \%$ rumen fluid, and $0.5 \%$ yeast extract with an inoculum constituting $4 \%$ of the total volume indicated that the shortest doubling time occurred within the first $2 \mathrm{~h}$ of incubation and was about $20 \mathrm{~min}$. The maximum optical density was reached after about $6 \mathrm{~h}$. Values for growth in medium prepared anoxically are similar, irrespective of whether reducing agent (cysteine plus sulfide) is added, but when air ( $2 \mathrm{ml}$ per $5 \mathrm{ml}$ of medium in 13-ml tubes) is added to medium without a reducing agent there is practically no growth. There is very little growth at $45^{\circ} \mathrm{C}$ and hardly any growth at $22^{\circ} \mathrm{C}$ relative to that at $39^{\circ} \mathrm{C}$, at which temperature there is good growth.

Characterization tests and $\mathbf{G}+\mathbf{C}$ content. Strain $A 12-1^{\mathbf{T}}$ does not liquefy gelatin or produce hydrogen sulfide; neither does it reduce nitrate, hydrolyze urea, or produce catalase. The $\mathrm{G}+\mathrm{C}$ content of the DNA is 40.5 mol\% (mean for four separate determinations; standard error of the mean, 0.64).

Cellular fatty acids. The major components of the cellular fatty acids of strain A12-1 ${ }^{\mathrm{T}}$ grown in medium without rumen fluid or volatile fatty acid mixture are saturated straight-chain $\mathrm{C}_{14: 0}$ and $\mathrm{C}_{16: 0}$ fatty acids and aldehydes (Table 3 ). Odd-chain and iso- and/or anteiso-fatty acids were found only in cells grown in media with rumen fluid $(40 \%$ [vol $/ \mathrm{vol}])$ or the volatile fatty acid mixture of Caldwell and Bryant (3). Thus, strain A12-1 ${ }^{\mathrm{T}}$ differs significantly in its fatty acid composition from Butyrivibrio fibrisolvens type strain $\mathrm{D} 1$, which has been reported to contain major amounts of $\mathrm{C}_{18: 1}$ cis 11 aldehydes (16) or $\mathrm{C}_{18: 1}$ fatty acids (12\% of total) (10).

Strain $A 12-1^{T}$ is the type strain and has been deposited in the Deutsche Sammlung von Mikroorganismen und Zellkulturen as strain DSM $9787^{\mathrm{T}}$.

Comments. As mentioned earlier, the older definitions of $B$. fibrisolvens would have included $P$. ruminis. It has long been recognized that bacteria classified as $B$. fibrisolvens include a wide variety of biotypes $(1,2,6,9,25)$. Thus, it is considered very likely that more strains, currently classified as $B$. fibrisol$v e n s$, will be found to differ significantly from the type strain and that they will be placed in other species or genera. The phenotypical characteristics which differentiate $B$. fibrisolvens and $P$. ruminis are that $P$. ruminis does not grow on xylan or starch and is not proteolytic (does not liquefy gelatin).
Whereas $B$. fibrisolvens cells contain major amounts of $C_{18}$ fatty acids, $P$. ruminis cells do not. The tendency to produce very long cells, particularly when grown on agar media, is characteristic of $P$. ruminis but not of $B$. fibrisolvens.

Strain A12-1 ${ }^{\mathrm{T}}$ was isolated from a $10^{-8}$ dilution of rumen ingesta, which suggests that $P$. ruminis could contribute mean-

TABLE 3. Cellular fatty acid composition of strain A12-1 ${ }^{\mathrm{T}}$

\begin{tabular}{|c|c|c|c|c|}
\hline \multirow[b]{2}{*}{$\mathrm{ECL}^{a}$} & \multirow{2}{*}{ FAME $^{b}$} & \multicolumn{3}{|c|}{$\begin{array}{l}\text { Fatty acid composition }(\%)^{c} \text { of cells } \\
\text { grown in medium: }\end{array}$} \\
\hline & & Alone & $\begin{array}{l}\text { With rumen } \\
\quad \text { fluid }\end{array}$ & $\begin{array}{l}\text { With volatile } \\
\text { fatty acid } \\
\text { mixture }\end{array}$ \\
\hline 10.467 & UN & 1.0 & 0.2 & \\
\hline 12.000 & $12: 0$ & 0.6 & 1.2 & 0.4 \\
\hline 12.470 & $11: 0 \mathrm{dma}$ & 2.3 & 0.8 & \\
\hline 12.614 & i13:0 & & 0.3 & 1.6 \\
\hline 12.929 & $\begin{array}{l}13: 1 c 12 \text { or } \\
14: 0 \text { ald }\end{array}$ & $8.1^{d}$ & 4.1 & 1.8 \\
\hline 13.521 & UN & 2.0 & & \\
\hline 13.560 & i15:0 ald (?) & & 0.5 & 4.9 \\
\hline 14.000 & 14:0 & 27.3 & 12.9 & 6.8 \\
\hline 14.474 & $14: 0 \mathrm{dma}$ & 37.5 & 20.6 & 7.0 \\
\hline 14.622 & i15:0 & & 0.8 & 10.4 \\
\hline 14.950 & $16: 0$ ald & 0.5 & 0.7 & 0.5 \\
\hline 15.000 & $15: 0$ & & 4.7 & 6.4 \\
\hline 15.114 & $\mathrm{i} 15: 0 \mathrm{dma}$ & 0.5 & 2.8 & 23.4 \\
\hline 15.200 & ai15:0 dma & & 1.8 & 3.7 \\
\hline 15.474 & $\begin{array}{l}15: 0 \mathrm{dma} / \\
14: 03 \mathrm{OH}(?)\end{array}$ & & 3.2 & 2.7 \\
\hline 16.000 & $16: 0$ & 15.6 & 26.8 & 18.3 \\
\hline 16.473 & $16: 0 \mathrm{dma}$ & 3.7 & 5.5 & 2.4 \\
\hline 16.629 & i17:0 & & & 2.8 \\
\hline 17.857 & $18: 1 t 11(?)$ & & 1.7 & \\
\hline 18.000 & $18: 0$ & & 4.3 & \\
\hline 18.329 & UN & & 1.3 & \\
\hline 18.468 & $18: 0 \mathrm{dma}$ & & 1.3 & \\
\hline
\end{tabular}

${ }^{a}$ ECL, equivalent chain length.

${ }^{b}$ FAME, fatty acid methyl esters. i, iso; ai, anteiso; dma, dimethylacetal; ald, aldehyde; $c$, cis; $t$, trans; UN, unknown.

${ }^{c}$ Values are the percentages of the total fatty acids. Fatty acids amounting to less than $1 \%$ in all three preparations were omitted.

${ }^{d}$ Major fatty acids are given in boldface type. 
ingfully to fermentation in the rumen. The strain was obtained from a culture capable of fermenting succinate with the production of propionate. It remains to be seen whether succinate-fermenting isolates, morphologically similar to $\mathrm{A} 12-1^{\mathrm{T}}$, can be obtained from the succinate-fermenting culture.

\section{ACKNOWLEDGMENTS}

We thank Gabriele Pötter and Birgit Frerichs for their help with the cellular fatty acid analyses and Barbro Näslund for the volatile fatty acid analyses.

\section{REFERENCES}

1. Bryant, M. P. 1984. Genus Butyrivibrio Bryant and Small 1956, 18, emend. Moore, Johnson and Holdeman 1976, 241 AL , p. 641-643. In N. R. Krieg and J. G. Holt (ed.), Bergey's manual of systematic bacteriology, vol. 1. Williams $\&$ Wilkins, Baltimore.

2. Bryant, M. P., and N. Small. 1956. The anaerobic monotrichous butyric acidproducing curved rod-shaped bacteria of the rumen. J. Bacteriol. 72:16-21.

3. Caldwell, D. R., and M. P. Bryant. 1966. Medium without rumen fluid for nonselective enumeration and isolation of rumen bacteria. Appl. Microbiol. 14:794-801.

4. Collins, M. D., P. A. Lawson, A. Willems, J. J. Cordoba, J. FernandezGarayzabal, P. Garcia, J. Cai, H. Hippe, and J. A. E. Farrow. 1994. The phylogeny of the genus Clostridium: proposal of five new genera and eleven new species combinations. Int. J. Syst. Bacteriol. 44:812-826.

5. Cornick, N. A., N. S. Jensen, D. A. Stahl, P. A. Hartman, and M. J. Allison. 1994. Lachnospira pectinoschiza sp. nov., an anaerobic pectinophile from the pig intestine. Int. J. Syst. Bacteriol. 44:87-93.

6. Hespell, R. B. 1992. The genera Butyrivibrio, Lachnospira, and Roseburia, p. 2022-2033. In A. Balows, H. G. Trüper, M. Dworkin, W. Harder, and K.-H. Schleifer (ed.). The prokaryotes, 2nd ed., vol. 2. Springer-Verlag, New York.

7. Holdeman, L. V., E. P. Cato, and W. E. C. Moore (ed.). 1977. Anaerobe laboratory manual, 4th ed. Virginia Polytechnic Institute and State University, Blacksburg.

8. Holdeman, L. V., and W. E. C. Moore. 1974. New genus, Coprococcus, twelve new species, and emended descriptions of four previously described species of bacteria from human feces. Int. J. Syst. Bacteriol. 24:260-277.

9. Hungate, R. E. 1966. The rumen and its microbes. Academic Press, Inc., New York.

10. Ifkovits, R. W., and R. S. Ragheb. 1968. Cellular fatty acid composition and identification of rumen bacteria. Appl. Microbiol. 16:1406-1413.

11. Jukes, T. H., and C. R. Cantor. 1969. Evolution of protein molecules, p. 21-132. In H. N. Munro (ed.), Mammalian protein metabolism. Academic Press, New York.

12. Leatherwood, J. M., and M. P. Sharma. 1972. Novel anaerobic cellulolytic bacterium. J. Bacteriol. 110:751-753.

13. Marmur, J. 1961. A procedure for the isolation of deoxyribonucleic acid from micro-organisms. J. Mol. Biol. 3:208-218.

14. Meier, A., P. Kirschner, K.-H. Schröder, J. Wolters, R. M. Kroppenstedt, and E. C. Böttger. 1993. Mycobacterium intermedium sp. nov. Int. J. Syst. Bacteriol. 43:204-209.

15. Meyer, S. A., and K. H. Schleifer. 1975. Rapid procedure for the approximate determination of the deoxyribonucleic acid base composition of micrococci, staphylococci, and other bacteria. Int. J. Syst. Bacteriol. 25:383385.

16. Moore, L. V. H., D. M. Bourne, and W. E. C. Moore. 1994. Comparative distribution and taxonomic value of cellular fatty acids in thirty-three genera of anaerobic gram-negative bacilli. Int. J. Syst. Bacteriol. 44:338-347.

17. Moore, W. E. C., and L. V. Holdeman. 1974. Human fecal flora: the normal flora of 20 Japanese-Hawaiians. Appl. Microbiol. 27:961-979.

18. Moore, W. E. C., and L. V. Holdeman Moore. 1986. Genus Eubacterium Prévot 1938, 294 AL p. 1353-1373. In P. H. A. Sneath, N. S. Mair, M. E. Sharpe, and J. G. Holt (ed.), Bergey's manual of systematic bacteriology, vol. 2. Williams \& Wilkins, Baltimore.

19. Moore, W. E. C., J. L. Johnson, and L. V. Holdeman. 1976. Emendation of Bacteroidaceae and Butyrivibrio and descriptions of Desulfomonas gen. nov. and ten new species in the genera Desulfomonas, Butyrivibrio, Eubacterium, Clostridium, and Ruminococcus. Int. J. Syst. Bacteriol. 26:238-252.

20. Nakazawa, F., and E. Hoshino. 1994. Genetic relationships among Eubacterium species. Int. J. Syst. Bacteriol. 44:787-790.

21. Rainey, F. A., M. Dorsch, H. W. Morgan, and E. Stackebrandt. 1992. 16 S rDNA analysis of Spirochaeta thermophila: position and implications for the systematics of the order Spirochaetales. Syst. Appl. Microbiol. 16:224-226.

22. Rainey, F. A., and E. Stackebrandt. 1993. 16S rDNA analysis reveais phyiogenetic diversity among the polysaccharolytic clostridia. FEMS Microbiol. Lett. 113:125-128.

23. Saitou, N., and M. Nei. 1987. The neighbor-joining method: a new method for reconstructing phylogenetic trees. Mol. Biol. Evol. 4:406-425.

24. Stanton, T. B., and D. C. Savage. 1983. Roseburia cecicola gen. nov., sp. nov., a motile, obligately anaerobic bacterium from a mouse cecum. Int. J. Syst. Bacteriol. 33:618-627.

25. Stewart, C. S., and M. P. Bryant. 1988. The rumen bacteria, p. 21-75. In P. N Hobson (ed.), The rumen microbial ecosystem. Elsevier Applied Science, London.

26. Ulitzur, S. 1972. Rapid determination of DNA base composition by ultraviolet spectroscopy. Biochim. Biophys. Acta 272:1-11.

27. Vainshtein, M., H. Hippe, and R. M. Kroppenstedt. 1992. Cellular fatty acid composition of Desulfovibrio species and its use in classification of sulfatereducing bacteria. Syst. Appl. Microbiol. 15:554-566.

28. van Gylswyk, N. O. 1980 . Fusobacteritum polysaccharolyticum sp. nov, a gram-negative rod from the rumen that produces butyrate and ferments cellulose and starch. J. Gen. Microbiol. 116:157-163.

29. van Gylswyk, N. O. 1995. Succiniclasticum ruminis gen. nov., sp. nov., a ruminal bacterium converting succinate to propionate as the sole energyyielding mechanism. Int. J. Syst. Bacteriol. 45:297-300. 